\title{
Implementation of a cattle manure biodigester for the production of gas for single family use
}

\author{
AS Mullo ${ }^{1}$, WE Sanchez ${ }^{1}$, and FW Salazar ${ }^{1} J M$ Chacha $^{2}$ and $A$. Flores ${ }^{2}$ \\ ${ }^{1}$ Universidad de la Fuerzas Armadas - ESPE Departamento de Eléctrica y Electrónica Sangolquí-Ecuador \\ ${ }^{2}$ Cotopaxi Technical University Electromechanical Engineering
}

\begin{abstract}
Cattle manure has an energy potential that is unknown to farmers. In the rural areas of the city of Latacunga - Ecuador there are inconveniences for the transport of the G.L. (Liquefied Petroleum Gas). For this reason, this document shows the implementation of a biodigester to obtain biogas for domestic use at Hacienda Terán located in La Dolorosa Belisario Quevedo, the cattle manure is analyzed, obtaining 13.7\% of total solids. In addition, it was established that $100 \mathrm{~kg}$ of mixture with the quantification of manure in a period of 12 days. In order to maintain the elevated temperature a greenhouse was built obtaining an average of $28.48^{\circ} \mathrm{C}$ in a time for the generation of biogas in 30 days and a minimum temperature of $22.7^{\circ} \mathrm{C}$. Temperatures that are within the limits established for the generation of biogas. With these parameters. a $4.25 \mathrm{~m} 3$ bio-bag was dimensioned generating a production of $1.1 \mathrm{~m} 3$ of gas that satisfies the family use of $0.7 \mathrm{~m} 3$ Biogas and G.L.P. firing tests were carried out up to $80^{\circ} \mathrm{C}$ obtaining a calorific value of $4800 \mathrm{kcal}$. per $\mathrm{m} 3$.
\end{abstract}

\section{Introduction}

The use of fossil fuels is increasing daily oil gas and coal reserves are increasing at the rate of 600 million barrels (Mb). 400 billion cubic feet (BCF) and 19.2 Giga tons of oil equivalent (GTOE) per year [4]. Especially the use of G.L.P. (Liquefied Petroleum Gas) is escalating with a daily energy demand which is the reason why there are environmental threats in recent years harmful to the welfare of humanity and the planet which include climate change global warming[1-2] pollution of the earth air and rivers polluted by animal manure pathogens. In rural areas it is difficult to transport G.L.P. for domestic use.

The use of alternative energies has a great impact for the care of the environment. in Ecuador a change of the energy matrix[3] has been implemented as an alternative to reduce environmental pollution and the rational use of energy. In order to treat solid bovine waste. the use of a Biodigester. The use of alternative energies has a great impact for the care of the environment. in Ecuador a change of the energy matrix[3] has been implemented as an alternative to reduce environmental pollution and the rational use of energy. In order to treat solid bovine waste. the use of a Biodigester has as its main function to minimize the contamination produced by cattle manure, rivers and lands where they are spilled. in addition to rural areas where the Biodigester is implemented has energy autonomy guaranteeing the quality of life. Biogas is not considered a common business source [4] but its impact is multiple as it can be used simultaneously in the production of electrical and thermal energy and as a fertilizer [5]. as shown in figure1.

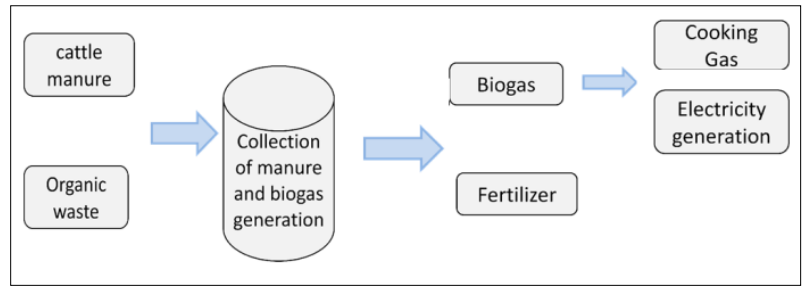

Figure. 1. Use of cattle manure for biogas and fertilizer generation.

In the rural area of La Dolorosa Belisario Quevedo (Latacunga- Ecuador) is a cattle ranch that has had an increase in population with it the need for fuels for domestic use. In this town it is difficult to transport G.L.P so deforestation has increased to obtain firewood and cattle is spilled in the fields and rivers of the place and others burn wood for cooking which has generated pollution problems and increased disease. This is why it is necessary to carry out research to reduce deforestation and diseases as well as to make good use of manure, it takes $0.8 \mathrm{~m} 3$ of GLP gas to satisfy the single family demand.

\subsection{The Biodigester}

A biodigestrer is a closed and hermetic container, inside which the organic substance substance is placed in combination of water - manure, for a time and at an 
average temperature of $30^{\circ} \mathrm{C}$ allows anaerobic degradation generating methane gas and fertilizers thus decreasing the polluting potential of excrement [6]. The biodigester can be constructed of brick cement and plastic forming an impermeable container that allows the generation of biogas

\subsection{Flexible structure (polyethylene balloon plants)}

digesters

This type of plant has in the upper part a bag digester in which gas is stored. the entrance and exit are in the same surface of the bag. Its advantages are low cost, easy transportation, little construction technology, high digestion temperatures. easy cleaning. maintenance and emptying. its disadvantages are its short lifespan. high receptivity to damage. low generations[6] [7].

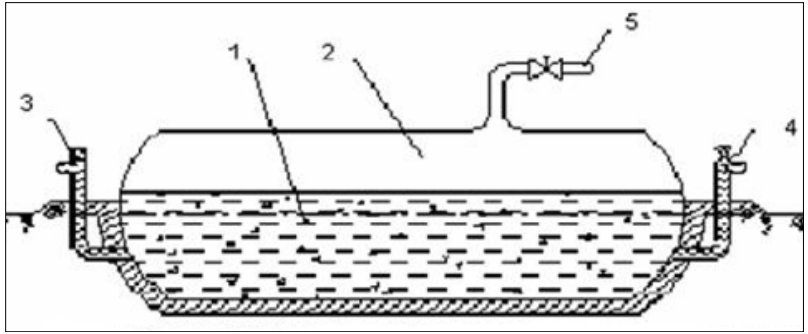

Fig. 2. Use of cattle manure for biogas and fertilizer generation.

Figure 2 shows a biodigester of common use in Andean zones with a protective structure. its components are: (1) Digester. (2) biogas container. (3) manure-water inlet. (4) Bio-fertilizer outlet and (5) gas outlet pipe.

\subsection{Chemical composition of cattle manure.}

derived from the digestive tract of animals. containing undigested residues of food. and digestive factors such as enzymes. gastric juices. pancreatic and dead cells of the intestinal mucous membrane. living and dead bacteria of the colon and waste products of animal metabolism. Within the chemical composition. manure is not just faecal matter. They are by-products of livestock production that include animal excrement. bedding. washing water. splashed feed. cleaners and hairs. Their composition varies between very large limits. depending on age. class and characteristics of the animals. quantity and digestibility of fodder. concentrated feed consumed by livestock. quantity and type of bed. duration. form of storage and method of handling manure. as shown in table 1[8].

\begin{tabular}{|c|c|c|c|c|c|}
\hline $\begin{array}{c}\text { Organic } \\
\text { matter }\end{array}$ & $\begin{array}{c}\text { Nitrogen } \\
\mathbf{( N )}\end{array}$ & $\begin{array}{c}\text { Phosphorus } \\
\mathbf{( P )}\end{array}$ & $\begin{array}{c}\text { Potassium } \\
\mathbf{( K )}\end{array}$ & $\begin{array}{c}\text { Magnesio } \\
\mathbf{( M g})\end{array}$ & $\begin{array}{c}\text { Humidity } \\
\%\end{array}$ \\
\hline 36,1 & 1,51 & 1,20 & 1,51 & 0,53 & 25,5 \\
\hline
\end{tabular}

Table 1. Chemical composition of sterol by mass (\%).

\subsection{Anaerobic digestion process}

Anaerobic digestion has four phases to generate biogas, which is the consequence of the degradation of microorganisms, thus forming the gas with a high methane content. In the substract (generic term to designate, in general, the food of microorganisms) there are 4 types of microorganisms that are characterized by their growth speed and according to the continuous degradation for example: the formation of $\mathrm{H} 2$, acetic acid or ammonia produced from amino acid acidogenesis [9], as shown in figure 3 .

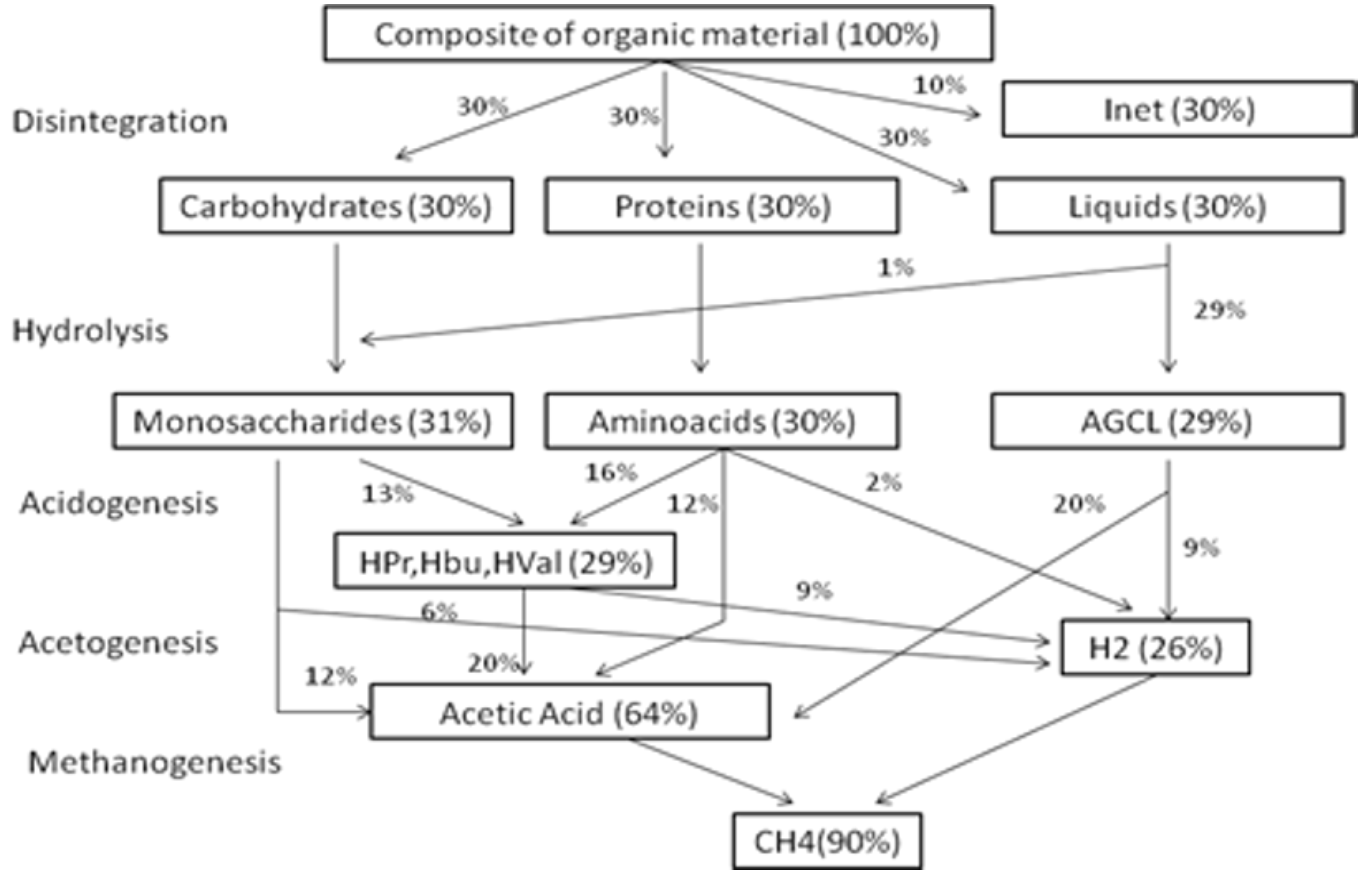

Figure. 2. Stages of anaerobic digestion . 
In the methanogenic stage, a large group of strict anaerobic bacteria is generated, which act on the products resulting from the previous stages. Methanogenic microorganisms can be considered as the most important ones within anaerobic microorganisms, since they are responsible for the formation of methane and the elimination of the environment from the products of the previous groups, being, moreover, the ones that give name to the general process of biomethanization. Methanogenic microorganisms complete the anaerobic digestion process by forming methane from monocarbonate substrates or with two carbon atoms bound together by a covalent bond: acetate, $\mathrm{H} 2 / \mathrm{CO} 2$,

Table 2. Chemical composition of biogas.

\begin{tabular}{|c|c|c|}
\hline $\begin{array}{c}\text { Chemical } \\
\text { Compound }\end{array}$ & Chemical formula & $\begin{array}{c}\text { Volumen } \\
\%\end{array}$ \\
\hline METHANE GAS & $\mathrm{CH}_{4}$ & $60-70$ \\
\hline $\begin{array}{c}\text { CARBON DIOXEDE } \\
\text { GAS }\end{array}$ & $\mathrm{CO}_{2}$ & $30-40$ \\
\hline HYDROGEN & $\mathrm{H}_{2}$ & 1.0 \\
\hline NITROGEN & $\mathrm{N}_{2}$ & 0.5 \\
\hline $\begin{array}{c}\text { CARBONO } \\
\text { MONOXIDE }\end{array}$ & $\mathrm{CO}$ & 0.1 \\
\hline OXYGEN & $\mathrm{O}_{2}$ & 0.1 \\
\hline SULFHIDRIC ÁCID & $\mathrm{H}_{2} \mathrm{~S}$ & 0.1 \\
\hline
\end{tabular}

format, methanol and some methylamines [10], as shown in figure 4.

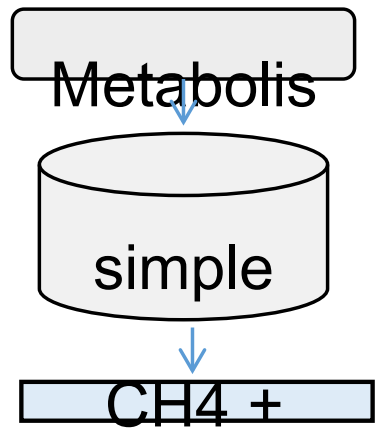

Figure. 4. Stages of metanizacion (methane gas generation) .

\subsection{The Biogas.}

Biogas is simply the fusion of two main elements, methane and carbon dioxide $(\mathrm{CH} 4$ and $\mathrm{CO} 2$ respectively), produced by the fermentation of organic matter under anaerobic conditions (absence of oxygen) [5] [11]. It has similar characteristics to natural gas. Around different environments, we find a great variety

Table 3. Chemical composition of biogas.

\begin{tabular}{|c|c|c|c|c|}
\hline Day & $\begin{array}{l}\text { Daily } \\
\text { weight } \\
\text { ( kg ) }\end{array}$ & $\begin{array}{c}\text { Daily } \\
\text { weight (lb) }\end{array}$ & $\begin{array}{c}\text { Daily } \\
\text { weight } \\
\text { (kg) }\end{array}$ & $\begin{array}{c}\text { Daily } \\
\text { weight } \\
\text { (lb) }\end{array}$ \\
\hline 1 & 48 & 105,8 & \multirow{10}{*}{50,0} & \multirow{10}{*}{110,2} \\
\hline 2 & 49 & 108,0 & & \\
\hline 3 & 51 & 112,4 & & \\
\hline 4 & 50 & 110,2 & & \\
\hline 5 & 52 & 114,6 & & \\
\hline 6 & 49 & 108,0 & & \\
\hline 7 & 52 & 114,6 & & \\
\hline 8 & 48 & 105,8 & & \\
\hline 9 & 52 & 114,6 & & \\
\hline 10 & 49 & 108,0 & & \\
\hline
\end{tabular}

of organic waste such as animal manure, vegetable waste and different domestic waste that processed in a good way would generate biogas. The composition of the biogas is methane and carbon dioxide among other components [12]detailed below table 2:

\subsection{The PH index}

In order for the biogas generation process to develop satisfactorily. the $\mathrm{pH}$ must not fall below 6.0 or rise above 8.0. The $\mathrm{pH}$ value in the digester determines not only the biogas production but also its composition. One of the consequences of a fall in $\mathrm{pH}$ below 6 is that the biogas generated is very poor in methane and therefore has less energy potential. Since methanogenesis is considered to be the limiting stage of the process. it is necessary to keep the $\mathrm{pH}$ of the system close to neutrality. Acidogenic acids are significantly less sensitive to more extreme $\mathrm{pH}$ values. as shown in figure 5 .

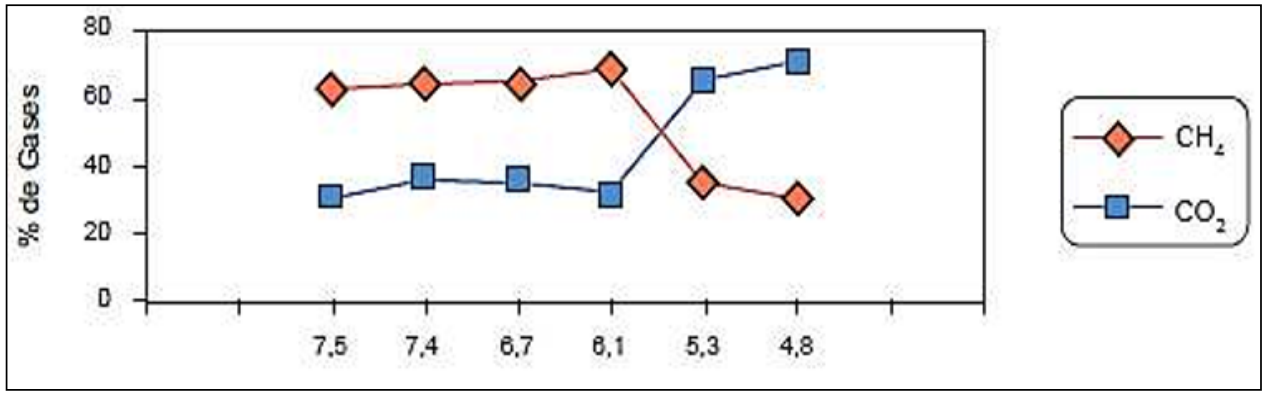

Figure. 5. pH of tuna-guano mixtures 


\section{Construction of a Polyethinene Bag Bio-Digester}

\subsection{Quantity of manure production in the stable.}

For the design, a field analysis was carried out to determine the daily amount of fresh manure, with a total of 10 Holstein cows weighing approximately $400 \mathrm{~kg}$, resting in a corral at night, the manure was collected with a daily quantity of 20 liters of volume during a period of 10 days at 7:30 a. m.., Table 3 shows that there is a daily production of $50 \mathrm{~kg}$ of manure:

\subsection{Determination of the daily charge to the Biodigester}

Consideration was given to the amount of manure generated daily in the stable, a ratio of 1:1 (1 kg of fresh manure +1 litre of water), due to the percentage of humidity which is greater than half, as the ratio is equal, then $1 \mathrm{~kg}=1$ litre. The density of the manure is almost equal to the density of the water for this reason the mixing ratio is assumed. Then:

VCD $=100 \mathrm{~kg}$
VDC: Daily storage volume.

\subsection{Dimensioning of the flexible structure polyethylene bag biodigester}

To calculate the liquid part corresponding to $75 \%$ of the biodigester, the retention time is taken into account, using equation 1 we have:

$\mathbf{V L}=100$ litres/day*30 days

$\mathbf{V L}=3000$ litres

$\mathbf{V L}=3 \mathrm{~m}^{3}$

Volume of the gaseous (V.G.) part 25\%, and we add a 5\% safety factor.

VG $=1200$ litres

VG $=1200$ litres $* \mathrm{~m}^{3} /($ (1000 litres $)$

$\mathbf{V G}=1.2 \mathrm{~m}^{3}$

With the results of liquid volume and gaseous volume, it was replaced in equation 3 to obtain the total volume.

$\mathbf{V T}=4200$ litros

VT $=4200$ litros* $\mathrm{m}^{3} /(1000$ litros $)$

$\mathbf{V T}=4,2 \mathrm{~m}^{3}$

In order to calculate the length of the Biodigester, the selected site and the availability of a $3 \mathrm{~m}$ wide low density tubular polyethylene thermoplastic roll of $3 \mathrm{~m}$ wide from equation 4 was taken into account in the stable:

$\mathbf{D}=0.95 \mathrm{~m}$
With the diameter, the length required for the Biodigester is calculated from equation 5 .

$\mathbf{L}=6 \mathrm{~m}$

The dam of the Biodigester was dimensioned based on the length and diameter of the Biodigester, covered all the dam with plastic to avoid landslides, also in the floor it was designed with a difference in level of $2^{\circ}$, with the purpose of the easy flow of the biofertilizer to the irrigation channel.

$\mathbf{L i}=$ lower length equal to the length of the Biodigester.

$\mathbf{L i}=6 \mathrm{~m}$

The depth is equal to the diameter of the Biodigester:

PD = D. $(3 / 4)$

PD $=$ Dyke depth .

$\mathbf{P D}=0.71 \mathrm{~m}$

The width of the lower and upper part is equal to the diameter of the Biodigester.

AD = Dyke width .

AD $=0,95$

The upper length of the dike is calculated on the basis of the side walls which have an inclination of $45^{\circ}$ :

Ls = Upper length.

$\mathrm{Ls}=7,42 \mathrm{~m}$

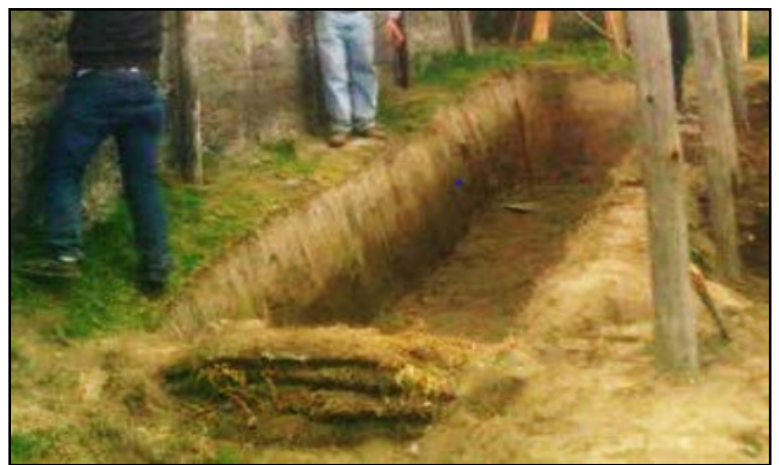

Fig. 6. Construction of the polyethylene digester tank

\subsection{Design and construction of the greenhouse for the biodigester.}

The temperature is one of the most important factors in the process of decomposing the mixture inside the biodigester. With the construction of the greenhouse, temperatures ranging from $20^{\circ}$ to $35^{\circ} \mathrm{C}$ were achieved and an average of $28^{\circ} \mathrm{C}$, and it also protects the bio-bag from environmental factors such as rain, wind and sun, which allows greater durability.

The dimensions taken into consideration for the construction of the greenhouse are: Length 2.6 meters, width 1.7 meters and height 1.3 meters to keep the area warm, as can be seen in the figure 7 . 


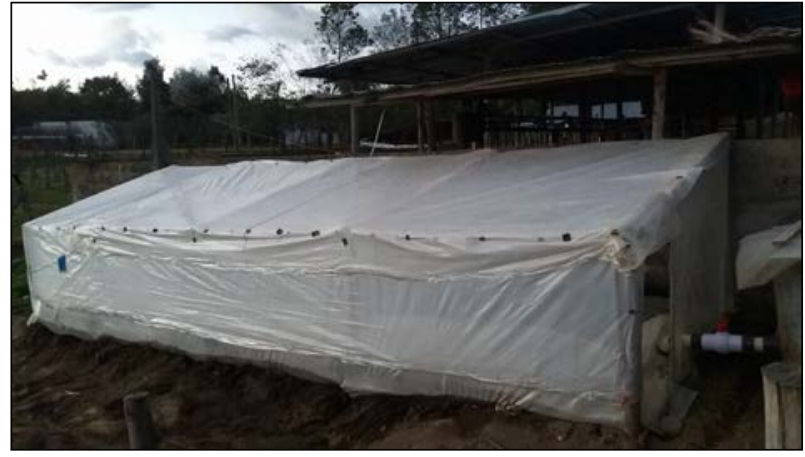

Figure. 7. Greenhouse for the bio-digester of Hacienda Terán.

\subsection{Gas Transport Pipe}

Once the bio-bag is placed in the slump basin, the transport piping is placed according to the planned layout, with the following materials, the installation can be seen in figures 8 and 9:

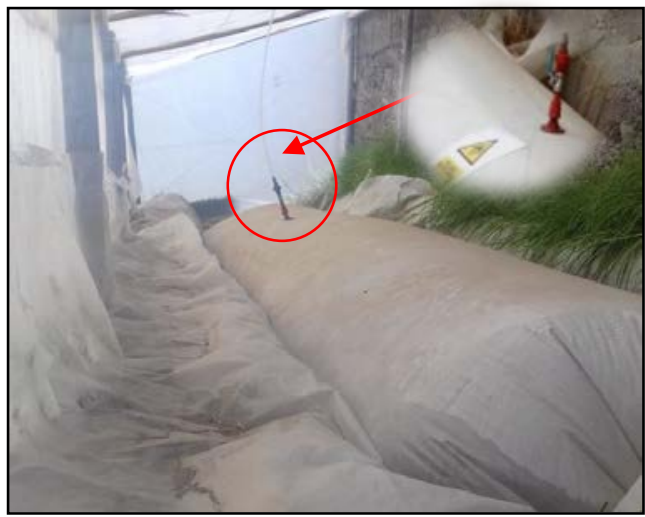

Fig. 8. Biogas output piping from the Biodigester.

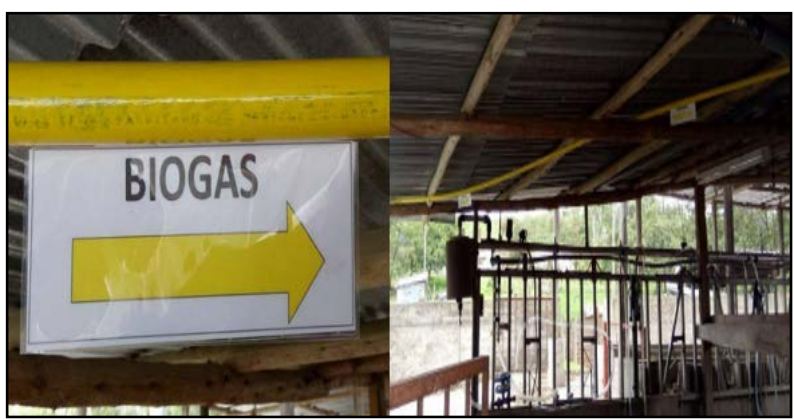

Figure. 9. Transport of the biogas by means of a yellow polyethylene pipe.

\subsection{Safety valve, moisture filter and sulfuric acid filter}

The generation of daily gas creates pressure, it is necessary to avoid that the pressure increases, for this reason at the end of the transport line was implemented a biogas safety valve, a simple exhaust mechanism the same that was made from a 4-litre plastic bottle. The humidity filter was placed to lower the water vapour levels in the biogas, to obtain a cleaner combustion. The biogas has a characteristic smell similar to rotten egg, this is due to a percentage of sulfuric acid contained in the gas, to eliminate sulfuric acid was implemented a steel stamen filter, as can be seen in the figure 10 .

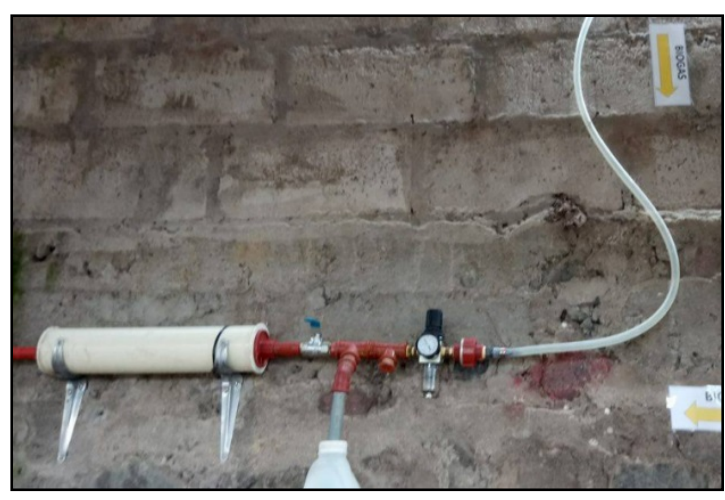

Figure. 9. Biogas outlet, filter and valve unit.

\section{Analyses of Results Obtained}

\subsection{Daily and monthly Biogas production.}

According to the design characteristics of the Biodigester daily measurements were made to generate the biogas whose daily production is 1050 liters or $1.05 \mathrm{~m} 3$. Amount of daily energy produced by the biodigester:

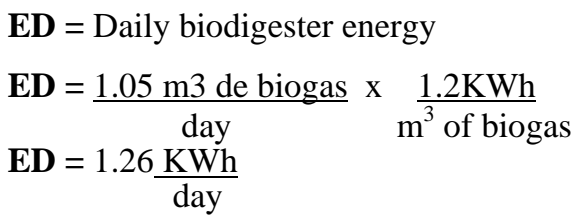

Calculation of monthly energy production:

$\mathbf{E M}=$ Monthly energy:

$\mathbf{E M}=38.32 \mathrm{KWh} /$ month

Comparative analysis of daily consumption of GLP and biogas.

$$
\begin{aligned}
& \frac{15 \mathrm{~kg} \text { de GLP }}{(1,5) \text { monthy }} * \frac{1 \mathrm{~m}^{3} \text { biogas }}{0,45 \mathrm{~kg} \text { GLP }}=22,2 \frac{\mathrm{m}^{3} \text { biogas }}{\text { monthly }} \\
& 22,2 \frac{\mathrm{m}^{3} \text { de biogas }}{\text { monthly }} * \frac{12 \text { months }}{1 \text { year }} * \frac{1 \text { year }}{365 \text { days }} \\
& =0,72 \frac{\mathrm{m}^{3} \text { de biogas }}{\text { day }} \\
& 0,72 \frac{\mathrm{m}^{3} \text { de biogas }}{\text { day }} * \frac{1,2 \mathrm{kWh}}{1 \mathrm{~m}^{3} \text { de biogas }}=0,86 \frac{\mathrm{kWh}}{\text { day }}
\end{aligned}
$$

\subsection{Characterization of biogas}

The characterisation of the energy potential was carried out in gas tests in the Chemistry Laboratory of the National Polytechnic School. And boiling time tests were 
performed on one liter of water. with biogas and L.P.G.

Table 4: Chemical characterization of biogas.

\begin{tabular}{|l|c|c|}
\hline COMPONENT & \% WEIGHT & \% Mol \\
\hline Nitrogen & 4.27 & 3.97 \\
\hline Oxygen & 3.64 & 2.96 \\
\hline Methane & 36.77 & 59.91 \\
\hline CO $_{2}$ & 54.88 & 32.51 \\
\hline H2O & 0.45 & 0.65 \\
\hline
\end{tabular}

Table 5: Energetic characteristic of biogas.

\begin{tabular}{|l|c|}
\hline \multicolumn{1}{|c|}{ Characteristics } & OUTCOMES \\
\hline Relative density & 0.904 \\
\hline Average molecular weight $(\mathrm{g} / \mathrm{mol})$ & 26.07 \\
\hline Calorific value exceeding $25^{\circ} \mathrm{C}(\mathrm{Btu} / \mathrm{lb})$ & 14294.81 \\
\hline Calorific value exceeding $25^{\circ} \mathrm{C}\left(\mathrm{Btu} / \mathrm{ft}^{3}\right)$ & 968.19 \\
\hline Calorific value below $25^{\circ} \mathrm{C}(\mathrm{Btu} / \mathrm{lb})$ & 1281.56 \\
\hline Calorific value below $25^{\circ} \mathrm{C}\left(\mathrm{Btu} / \mathrm{ft}^{3}\right)$ & 872.47 \\
\hline
\end{tabular}

\subsection{Temperature and relative humidity in the biodigester}

The Figure 11 shows that the construction of the greenhouse maintains the temperature at an average of $28^{\circ} \mathrm{C}$. and within the bio-bag it maintains an average of $32^{\circ} \mathrm{C}$. this temperature guarantees the biogas generation process. obtaining the following results:

Tmin: $20.1^{\circ} \mathrm{C}$.

Average $=28.2^{\circ} \mathrm{C}$.

$\operatorname{Tmax}=34.1^{\circ} \mathrm{C}$.

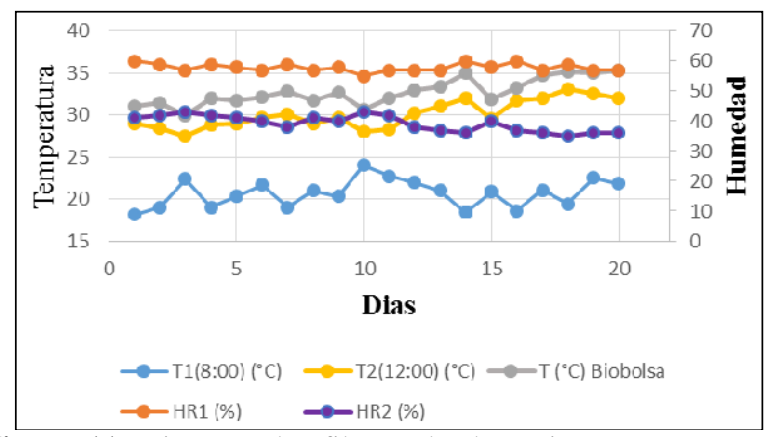

Figure. 11. Biogas outlet. filter and valve unit.

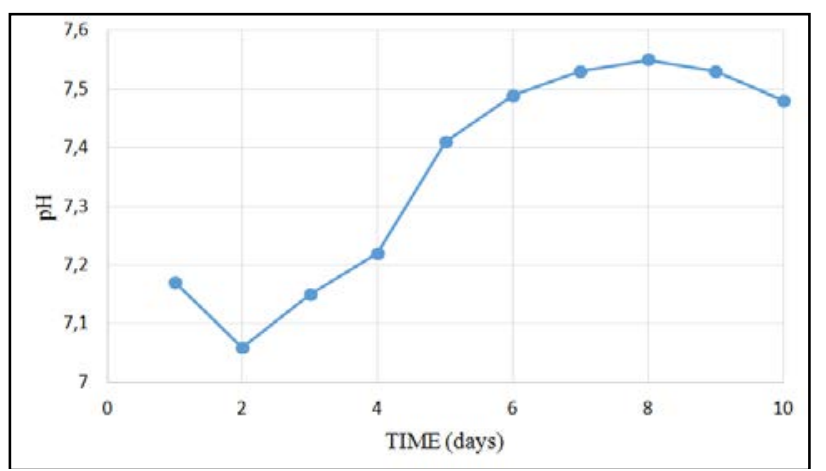

Figure. 12. $\mathrm{pH}$ behaviour over time.
Table 6. Temperature and relative humidity inside the greenhouse.

\begin{tabular}{|c|c|c|c|c|c|}
\hline \multicolumn{5}{|c|}{$\begin{array}{l}\text { TEMPERATURE AND RELATIVE HUMIDITY } \\
\text { INSIDE THE GREENHOUSE }\end{array}$} & \multirow{2}{*}{$\begin{array}{l}\text { TEMPERATU } \\
\text { RE INSIDE } \\
\text { THE BIOBAG } \\
\text { T3(12:00) }\left({ }^{\circ} \mathrm{C}\right)\end{array}$} \\
\hline Day & $\begin{array}{c}\text { T1(8:00) } \\
\left({ }^{\circ} \mathrm{C}\right)\end{array}$ & $\begin{array}{l}\text { HR1 } \\
(\%)\end{array}$ & $\begin{array}{l}\text { T2(12:00 } \\
)\left({ }^{\circ} \mathrm{C}\right)\end{array}$ & $\begin{array}{l}\text { HR2 } \\
(\%)\end{array}$ & \\
\hline 1 & 18,1 & 60 & 29 & 41 & 31 \\
\hline 2 & 19 & 59 & 28,4 & 42 & 31,5 \\
\hline 3 & 22,4 & 57 & 27,5 & 43 & 30 \\
\hline 4 & 19 & 59 & 28,9 & 42 & 32 \\
\hline 5 & 20,3 & 58 & 29 & 41 & 31,7 \\
\hline 6 & 21,7 & 57 & 29,7 & 40 & 32,2 \\
\hline 7 & 19 & 59 & 30,1 & 38 & 32,9 \\
\hline 8 & 21 & 57 & 29 & 41 & 31,8 \\
\hline 9 & 20,3 & 58 & 29,7 & 40 & 32,7 \\
\hline 10 & 24 & 55 & 28,1 & 43 & 30,7 \\
\hline 11 & 22,7 & 57 & 28,3 & 42 & 32 \\
\hline 12 & 22 & 57 & 30,2 & 38 & 33 \\
\hline 13 & 21 & 57 & 31 & 37 & 33,4 \\
\hline 14 & 18,4 & 60 & 32 & 36 & 35 \\
\hline 15 & 20,9 & 58 & 29,6 & 40 & 31,9 \\
\hline 16 & 18,6 & 60 & 31,7 & 37 & 33,2 \\
\hline 17 & 21,1 & 57 & 32 & 36 & 34,8 \\
\hline 18 & 19,4 & 59 & 33,1 & 35 & 35,2 \\
\hline 19 & 22,5 & 57 & 32,6 & 36 & 35 \\
\hline \multirow[t]{2}{*}{20} & 21,8 & 57 & 32 & 36 & 35,3 \\
\hline & 20,66 & 58 & 30,1 & 39 & 32,77 \\
\hline
\end{tabular}

In order to monitor the correct functioning of the biodigester. daily data was taken from the $\mathrm{pH}$. which is within the established ranges of 6 - 8 for a better biogas quality. which does not need the addition of a substance for $\mathrm{pH}$ regulation. the behavior can be observed in the figure 12.

\section{Conclusions and Recommendation}

\subsection{Conclusions}

- According to the design of the biodigester. it maintains a gas production of $1.05 \mathrm{~m} 3$ of biogas that satisfies the single- family demand of $0.85 \mathrm{~m} 3$ of G.L.P. gas. with an average temperature of $28^{\circ} \mathrm{C}$ and an average $\mathrm{pH}$ of 7.3 that generates a methane with good calorific characteristics.

- According to laboratory tests. methane gas has a calorific value of 968.19 (BTU/ft3) and a methane concentration percentage of 59.91 (\% moles). which maintain optimal calorific characteristics to be used as a family gas. The time required to heat 2 litres of water with the biogas until reaching $80^{\circ} \mathrm{C}$ is $8 \%$ higher than that of a LPG gas maintains a calorific value of the same characteristics. 


\subsection{Recommendation}

It is necessary to dimension the biodigester according to the family needs that the technical and economic characteristics are analyzed. Disseminate the project to rural areas that have a cattle manure production that allows to generate biogas for single family consumption

\section{References}

1. N. Abas. A. Kalair. and N. Khan. "Review of fossil fuels and future energy technologies". Futures. vol. 69. pp. 31-49. May 2015.

2. A. Schmidt. B. E. Law. C. Hanson. and O. Klemm "Distinct global patterns of strong positive and negative shifts of seasons over the last 6 decades" Atmospheric and Climate Sciences. vol. 2 (1). pp. 76 -88. Jan. 2012.

3. M. Castro. "Hacia una Matríz Energética Diversificada en el Ecuador”. Centro Ecuatoriano de Derecho Ambiental. vol. 1. pp.15 . (2010)

4. N. Abas. A. Kalair. and N. Khan. "Review of fossil fuels and future energy technologies”. Futures. vol. 69. pp. 31-49. May 2015.

5. M. A. Ehsan. C. K. Das. and Mahadi Hasan. "Biogas Based Chain Business: A Road to Sustainable Rural Development”. Conference (ICDRET). Jan 2016.

6. R. Botero and T.R. Preston. "Biodigestor de bajo costo para la producción de combustible y fertilizante a partir de excretas“ www.produccionnimal.com.ar/Biodigestores/04-biodigestores.pdf. 1987.

7. T. Arias and L. Lopez Ríos. "Technology proposal for the energy use of the shake bagasse barley from Hatueybrewery”.http://scielo.sld.cu/scielo.php?script =sci_artte xt\&pid=S2224-61852015000300001. ISSN 2224-618. Santiago de Cuba. 2015.

8. ACPA. "Estiércol bobino Mitos y realidades". http://www.actaf.co.cu/revistas/Revista\%20ACPA/2 009/ REVISTA\%2004/17\%20ESTIERCOL\%20BOVINO .pdf Fondo Editorial IDAE. Revista Vol 36. 2009 .

9. Biomasa. "Digestores anaerobios" Fondo Editorial IDAE. Madrid 2007.

10. M. Varnero. “Manual de Biogas”. Santiago de Chile. Chile: Viale delle Terme di Caracalla. 2011.

11. W. Pattaraprakorn. R. Saikaew and P. Bhasaputra "Feasible Study of Biogas Energy for Thai Dairy Cooperative from Dairy cow Manure: The Potential and Economic Analysis”. Proceedings of the International Conference on Energy and Sustainable Development: Issues and Strategies. ESD 2010.

12. Semarnat and Sagarpa. "Especificaciones tecnicas para el Diseño y Construccion de Biodigestores”. Proceedings of the International Conference on Energy and Sustainable Development: Issues and Strategies. Mexico D.F.. Mexico: Firco 2010. 